\title{
Symulacja koncentracii aktywności gospodarczych na obszarze południowej Polski z wykorzystaniem modelu Orion
}

\author{
Simulation of Economic Activity Concentration \\ in Southern Poland with Use of the Orion Model
}

\begin{abstract}
Streszczenie: Praca badawcza porusza aspekt kształtowania się koncentracji aktywności gospodarczych na obszarze południowej Polski, a dokładniej na obszarze sześciu województw: województwa dolnośląskiego, opolskiego, śląskiego, świętokrzyskiego, małopolskiego i podkarpackiego. Głównym narzędziem badawczym jest wykorzystanie modelu decyzyjno-symulacyjnego Orion w budowie całościowego systemu gospodarczego regionu, zdolnego do symulowania eksperymentalnych zmian według określonych założeń. Metodologia pracy i główne założenia, związane przede wszystkim z kalibracją modelu, przyjmują, jeżeli to możliwe, podejście najbardziej obiektywne, niepodyktowane konkretnymi wizjami rozwoju oraz interwencjonizmem władz regionalnych i lokalnych w planowaniu rozwoju gospodarczego; zakłada się ciągłość dotychczasowego procesu rozwoju poszczególnych aktywności gospodarczych. Praca posiada silne tło prognostyczne, traktuje wynikowy stan badania jako stan na rok 2030. Wynikiem badań jest zatem prognozowany stan rozmieszczenia aktywności, a dokładniej, stan modelowy, do którego dąży skonstruowany system gospodarczy. Na tak ustalonej podstawie można wysnuć odpowiednie wnioski, zgodne z przyjętą metodologią parametryzacji modelu i pewnym stopniem uogólnienia problematyki złożonych mechanizmów gospodarczych, które ukierunkowują i ograniczają możliwości interpretacyjne.
\end{abstract}

\begin{abstract}
The research brings up the issue of formation of economic activity concentration in southern Poland, namely in six provinces: dolnośląskie, opolskie, śląskie, świętokrzyskie, małopolskie and podkarpackie. The main means of research is the use of Orion decision-simulation model in the process of creation of a comprehensive economic system of the region, capable of simulating experimental changes according to predefined assumptions. The work methodology and main assumptions, related mainly to the model calibration, adopt - whenever possible - the most objective approach, unaltered by any specific visions of development or local and regional authorities' interventionism aimed at the plans of economic development. It assumes the continuity of previous processes of development of particular economic activities. The work possesses a strong prognostic background, projecting the results as a prediction for the year 2030. Therefore, the result comprises a predicted distribution of activities; more precisely, a model state, which the prepared economic system aims to achieve. This provides a basis to formulate appropriate conclusions, according to the adopted methodology of model parameterization and a certain degree of generalization of issues concerning complex economic mechanisms that direct and restrict interpretative possibilities.
\end{abstract}

Słowa kluczowe: aktywność gospodarcza; koncentracje; model symulacyjno-decyzyjny Orion; prognoza; system gospodarczy

Keywords: concentration; economic activity; economic system; Orion decision-simulation model; prognosis 
Otrzymano: 20 grudnia 2015

Received: 20 December 2015

Zaakceptowano: 6 czerwca 2016

Accepted: 6 June 2016

\section{Sugerowana cytacja / Suggested citation:}

Krygier, M. (2016). Symulacja koncentracji aktywności gospodarczych na obszarze południowej Polski z wykorzystaniem modelu Orion. Prace Komisji Geografii Przemysłu Polskiego Towarzystwa Geograficznego, 30(2), 209-225.

\section{WSTĘP}

Koncentracja i lokalizacja są ważnymi czynnikami wpływającymi na działalność i konkurencyjność przedsiębiorstw oraz regionów, przede wszystkim dzięki korzyściom aglomeracji (Domański, 2006), wpływającym nie tylko na sektor produkcyjny, związany z komplementarnością procesów produkcji, ale także na ogólną działalność gospodarczą, gdzie interakcje między dużymi grupami osób i instytucji w unikalnych strukturach społeczno-gospodarczych znacznie zwiększają szansę na powstawanie nowych funkcji, przedsięwzięć i specjalistycznych usług (Ponsard, 1992). Koncentracje zwiększają także szansę powodzenia wdrażanych innowacyjnych programów rozwojowych, a przede wszystkim tworzą duży zasób kapitału i wiedzy, który przy odpowiedniej konsolidacji działań może być głównym czynnikiem rozwoju. Ważna jest także identyfikacja nieodkrytego potencjału obszarów, których włączenie i aktywizacja może doprowadzić do osiągnięcia zamierzonych efektów synergii. Ostateczna efektywność działania systemu gospodarczego w dużej mierze zależy od obywateli, ich rzeczywistych, często niepoliczalnych i trudnych do zdefiniowania decyzji wywołujących określone konsekwencje przestrzenne (Törnqvist, 1977); jednak duży wpływ na kreowanie środowiska mają także państwo i samorządy terytorialne przez tworzenie odpowiedniego otoczenia instytucjonalnego, prawnego i motywacyjnego wspierającego przedsiębiorczość i innowacyjność, zapewnienie infrastruktury, realizację odpowiednich inwestycji publicznych i dążenie do harmonijnego rozkładu aktywności na określonym obszarze (Perreur, 1992). Konsolidacja działań i syntetyczne podejście do zagadnień gospodarki przestrzennej, jako wysoce złożonego systemu przepływów i przemieszczeń ludzi, towarów, energii, kapitału itp. (Regulski, 1985), wydaje się być odpowiednią drogą w poznawaniu, rozumieniu i kreowaniu procesów środowiska gospodarczego.

Przedstawione badania są próbą całościowego podejścia do gospodarki rozumianej jako system, obejmują całokształt działalności gospodarczych w podziale na sekcje PKD 2007. Głównym narzędziem badawczym będącym bazą teoretyczną i strukturyzującym badania jest model symulacyjno-decyzyjny Orion (Brzuchowska, Litwińska, Ossowicz, Sławski, Zipser, 1994). Ideologia badań polega przede wszystkim na konstrukcji eksperymentalnego modelu gospodarczego uwzględniającego lokalne predyspozycje i interakcje pomiędzy poszczególnymi przedsiębiorstwami oraz ustaleniu stanu wejściowego do symulacji określającego globalne, prognostyczne ramy dla całego obszaru; najważniejszym etapem jest przeprowadzenie symulacji, gdzie dzięki procedurom zawartym w modelu Orion następuje stopniowy, iteracyjny proces koncentracji przedsiębiorstw 
i strukturalizacja globalnych, prognostycznych założeń. Otrzymany obraz może wspomóc wykrycie potencjałów lokalizacyjnych i inwestycyjnych poszczególnych rejonów w strukturze całego obszaru. Wyniki dają możliwość szerokiego wnioskowania, jednak należy pamiętać, że przyjęta metodologia konstrukcji i parametryzacji modelu, związana z pewnym stopniem uogólnienia problematyki złożonych mechanizmów gospodarczych, ukierunkowuje i ogranicza możliwości interpretacyjne. Ze względu na ograniczoną objętość artykułu prezentacja metodologii i przebiegu badań koncentruje się przede wszystkim na głównych aspektach teoretycznych, pomijając szczegółowe wyjaśnienie mechanizmów, procedur obliczeniowych i pełnej parametryzacji modelu.

W całym procesie badawczym wykorzystano wiele danych; podstawowym działaniem jest ustalenie prognozowanej liczby przedsiębiorstw w poszczególnych sekcjach dla całego obszaru na podstawie analizy trendów w latach 1995-2012 i ekstrapolacji danych do roku 2030. W badaniach wykorzystano także inne dane, m.in. prognozy demograficzne, planowane modernizacje sieci komunikacyjnej, ocenę warunków agroekologicznych, lokalizację udokumentowanych złóż; ich celowość i wykorzystanie zostanie wyjaśnione w dalszej części artykułu.

\section{OBSZAR BADAŃ}

Główny obszar badań obejmuje południową Polskę, a dokładniej terytorium sześciu województw: województwo dolnośląskie, opolskie, śląskie, małopolskie, świętokrzyskie i podkarpackie. Obszar ten posiada ważne położenie w skali makroregionalnej, zdeterminowane w dużej mierze barierą górską od strony południowej, która przyczyniła się do powstania stabilnej, pasmowej struktury osadniczej. Tereny te są bogate w złoża kopalniane oraz posiadają cenne, urodzajne ziemie. Uwarunkowania geograficzne, historyczne oraz gospodarcze przyczyniły się do powstania dużych miast takich jak Wrocław, Opole, Katowice, Kraków, Kielce czy Rzeszów. Ważność tej struktury w skali kraju, dążenie do wzmocnienia jej przestrzennej i funkcjonalnej integracji odkreślana jest w różnych opracowaniach i strategiach planistycznych (KPZK 2030, 2011). Przez obszar przebiega kilka tras o znaczeniu europejskim, przede wszystkim trasa E40 - przebiegająca wzdłuż autostrady A4, głównego rdzenia komunikacyjnego; ale także inne, takie jak E65, E67, E77 czy DW371. Stwarzają one duży potencjał rozwojowy obszarów w tworzeniu silnego, konkurencyjnego rynku na arenie globalnej. Badania dotyczące wybranego obszaru oparte są na najniższym podziale administracyjnym, a mianowicie na podziale na jednostki gminne. W badanym obszarze znajduje się 851 gmin, w tym 32 miasta na prawach powiatu. Oprócz wymienionych województw, badania uwzględniają także najbliższe otoczenie, ze względu na potencjał ludnościowy obszarów przygranicznych, który odgrywa zasadniczą rolę w prowadzonych symulacjach. Na otoczenie składają się: 30 powiatów polskich, niemiecki powiat Görlitz, 16 powiatów czeskich, 18 powiatów (okresów) słowackich, 6 rejonów ukraińskich. Wyższy podział administracyjny całego otoczenia związany jest przede wszystkim z ujednoliceniem potencjałów obszarów; dokładniejsza granulacja, przy znacznych różnicach w podziałach administracyjnych krajów, mogłaby wywołać deformacje w wynikach symulacji. 


\section{MODEL ORION}

Model ORION należy do grupy modeli alokacyjnych, który służy do rozmieszczania różnych form działalności, w terminologii modelu zwanymi aktywnościami, w zadanym obszarze, mogący znaleźć zastosowanie w różnych dziedzinach zajmujących się szeroko pojętym planowaniem przestrzennym; zarówno do prognozowania rozwoju przestrzennego systemów osadniczych, jak i do optymalizacji struktur funkcjonalno-przestrzennych (Brzuchowska, Litwińska, Ossowicz, Sławski, Zipser, 1994). Jego teoretyczna konstrukcja została opracowana w roku 1976 przez T. Zipsera. Przez kolejne lata model był testowany, weryfikowany, odpowiednio rozwijany przez zespół badaczy i stosowany w licznych opracowaniach, m.in. dotyczących wartościowania koncepcji planu kierunkowego Krakowskiego Zespołu Miejskiego, przeprowadzenia serii symulacji wspomagających tworzenie Koncepcji Przestrzennego Zagospodarowania Kraju, wspomagania tworzenia Studium Uwarunkowań i Kierunków Zagospodarowania Przestrzennego dla miasta Wrocław, Kraków, Poznań czy Łódź.

Podstawą budowy i funkcjonowania modelu jest założenie, że przestrzeń osadnicza stanowi system, którego elementami są różnego rodzaju działalności generujące interakcje i posiadające wymagania lokalizacyjne. Ogólna konstrukcja modelu jest podporządkowana poszukiwaniu takiego układu przestrzennego aktywności, który według przyjętych parametrów charakteryzuje się stabilnością struktury. Na ostateczny wynik rozmieszczeń wpływają trzy procedury: procedura kontaktów, procedura predyspozycji i procedura konfliktów, które w ogólnej interpretacji oznaczają zapewnienie kontaktów między aktywnościami, dopasowanie się do lokalnych walorów terenu oraz zminimalizowanie sytuacji konfliktowych. Sekwencja symulacji wykonywana jest w sposób iteracyjny, a pełny proces obliczeń, rozpoczynający się od rozmieszczenia wstępnego, kończy się uzyskaniem stanu zbliżonego do równowagi.

\section{Model KONTAKTów}

Kontakty są jedną z fundamentalnych procedur zawartych w modelu Orion, a zarazem podlegają największemu rozwinięciu w prezentowanej pracy badawczej. Teoria modelu Orion zakłada istnienie pewnych aktywności (a dokładniej par), między którymi zachodzą przestrzenne relacje - istnieje pewna aktywność źródłowa, która w celu zaspokojenia kontaktu penetruje przestrzeń w poszukiwaniu aktywności docelowej. Penetracja zbioru następuje w skonstruowanym modelu przestrzennym, który składa się z punktów węzłowych reprezentujących potencjały badanych jednostek obszarowych oraz sieci, za pomocą której dochodzi do kontaktów między aktywnościami (ryc. 1).

W badaniach jako sieć przyjęto istniejący system komunikacji kołowej wraz z uwzględnieniem realizowanych i planowanych do realizacji do roku 2030 inwestycji i modernizacji; odcinki sieci są zróżnicowane pod względem możliwej średniej prędkości przenoszenia kontaktów (określonej na podstawie klas technicznych dróg), co wpływa na dostępność węzłów w całym modelu przestrzennym i wynik symulacji. 


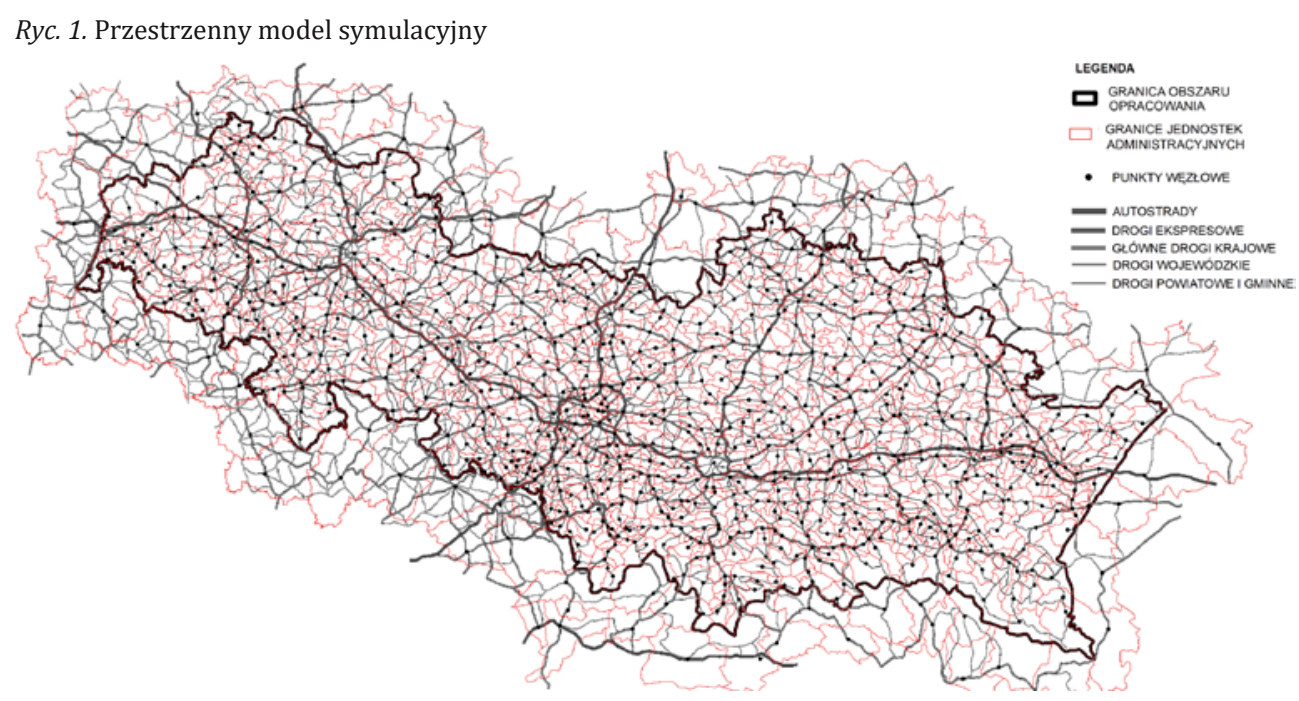

Źródło: opracowanie własne na podstawie Programu budowy dróg krajowych na lata 2011-2015 (2013)

Określenie listy aktywności jest często kluczowym elementem wypływającym wprost z celu wykorzystania modelu i dążenia do uzyskania zakładanych wyników. Głównym podziałem zastosowanym w pracy są sekcje PKD 2007. Zmodyfikowaniu uległa sekcja C, która grupuje liczne przedsiębiorstwa przetwórcze o różnym charakterze. Zasadniczym argumentem dla wprowadzenia podziału tej sekcji jest wyraźna różnica w warstwie kontaktowania się poszczególnych działów z tej sekcji z przedsiębiorstwami z pozostałych sekcji. Do listy aktywności została dodana także ludność, jako silny czynnik wpływający na rozmieszczenie aktywności gospodarczych, zarówno od strony tworzenia przedsięwzięć i współpracy, jak i jako potencjalny rynek zbytu dla produktów i usług oferowanych przez przedsiębiorstwa. Przy całościowym podejściu w konstruowaniu modelu gospodarczego, który wiąże się z pewnymi uogólnieniami i uproszczeniami, zdecydowano, że potencjał ludności będzie mierzony na podstawie ogólnej liczby mieszkańców. Na podstawie dostępnych danych oszacowano prognostyczny obraz sytuacji demograficznej dla poszczególnych jednostek na rok 2030 (ryc. 2). Jako miarę poszczególnych aktywności przyjęto liczbę przedsiębiorstw z danej sekcji, w przypadku aktywności Ludność, w celu zbilansowania parametrów, miara ta wyrażona jest w tysiącach mieszkańców; dane zostały zaczerpnięte z Banku Danych Lokalnych w kategorii podmioty gospodarki narodowej wg rejestru regon oraz stan ludności. Podsumowując, wyodrębniono 23 aktywności:

1. Sekcja A - Rolnictwo, leśnictwo, łowiectwo i rybactwo,

2. Sekcja B - Górnictwo i wydobywanie,

3. Sekcja $C^{*}$ - Przetwórstwo przemysłowe - działalność produkcyjna związana bezpośrednio z rolnictwem, leśnictwem, łowiectwem i rybactwem ("działy od 10 do 17),

4. Sekcja C $C^{* *}$ - Przetwórstwo przemysłowe - działalność produkcyjna związana bezpośrednio z górnictwem i wydobywaniem (**dział 19 oraz od 23 do 25), 
5. Sekcja $C^{* * *}$ - Przetwórstwo przemysłowe - produkcja zawierająca pozostałe, niesklasyfikowane działy (***działy 18, 20, 21, 22 oraz od 26 do 33),

6. Sekcja D - wytwarzanie i zaopatrywanie w energię elektryczną, gaz, parę wodną, gorącą wodę i powietrze do układów klimatyzacyjnych,

7. Sekcja E - dostawa wody; gospodarowanie ściekami i odpadami oraz działalność związana z rekultywacją,

8. Sekcja F - Budownictwo,

9. Sekcja G - Handel hurtowy i detaliczny; naprawa pojazdów samochodowych, włączając motocykle,

10. Sekcja $\mathrm{H}$ - Transport i gospodarka magazynowa,

11. Sekcja I - Działalność związana z zakwaterowaniem i usługami gastronomicznymi,

12. Sekcja J - Informacja i komunikacja,

13. Sekcja K - Działalność finansowa i ubezpieczeniowa,

14. Sekcja L - Działalność związana z obsługą rynku nieruchomości,

15. Sekcja M - Działalność profesjonalna, naukowa i techniczna,

16. Sekcja N - Działalność w zakresie usług administrowania i działalność wspierająca,

17. Sekcja 0 - Administracja publiczna i obrona narodowa; obowiązkowe zabezpieczenia społeczne,

18. Sekcja P - Edukacja,

19. Sekcja Q - Opieka zdrowotna i pomoc społeczna,

20. Sekcja R - Działalność związana z kulturą, rozrywką i rekreacją,

21. Sekcja S i T - Gospodarstwa domowe zatrudniające pracowników; gospodarstwa domowe produkujące wyroby i świadczące usługi na własne potrzeby oraz pozostała działalność usługowa,

22. Sekcja U - Organizacje i zespoły eksterytorialne,

23. Ludność.

Ryc. 2. Prognoza demograficzna na rok 2030

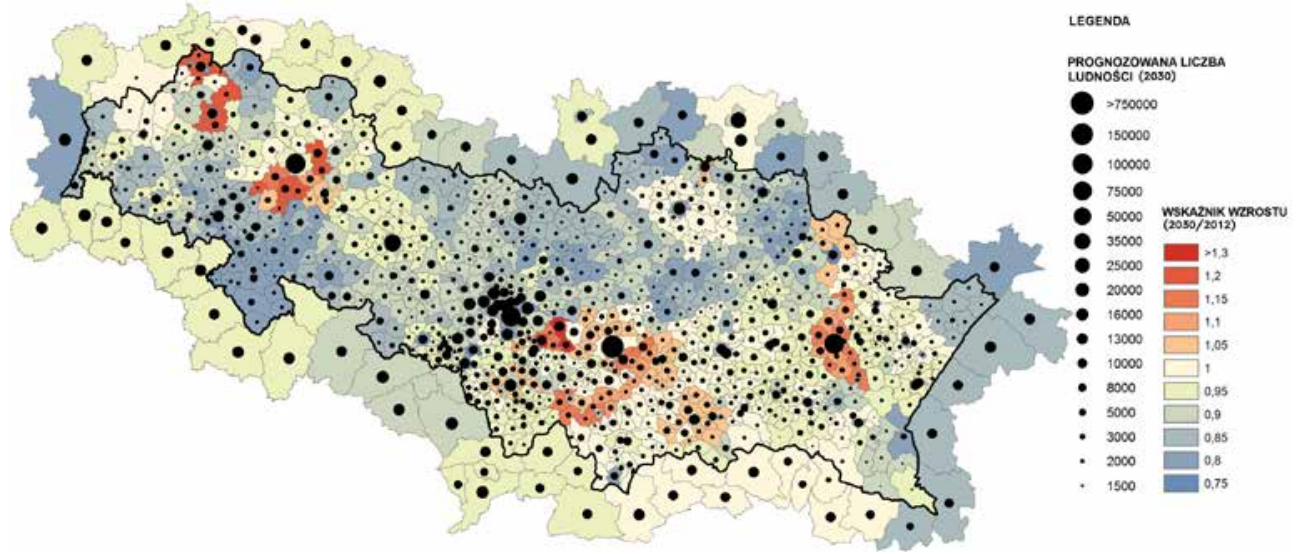

Źródło: opracowanie własne na podstawie danych z: Czech Statistical Office, State Statistics Service of Ukraine, Statistical Office of the Slovak Republic, Prognoza dla powiatów i miast na prawie powiatu oraz podregionów na lata 2011-2035. (2011), Regional population projections, EUROPOP2008: Most EU regions face older population profile in 2030 (2010) 
Ryc. 3. Modelowy system gospodarczy

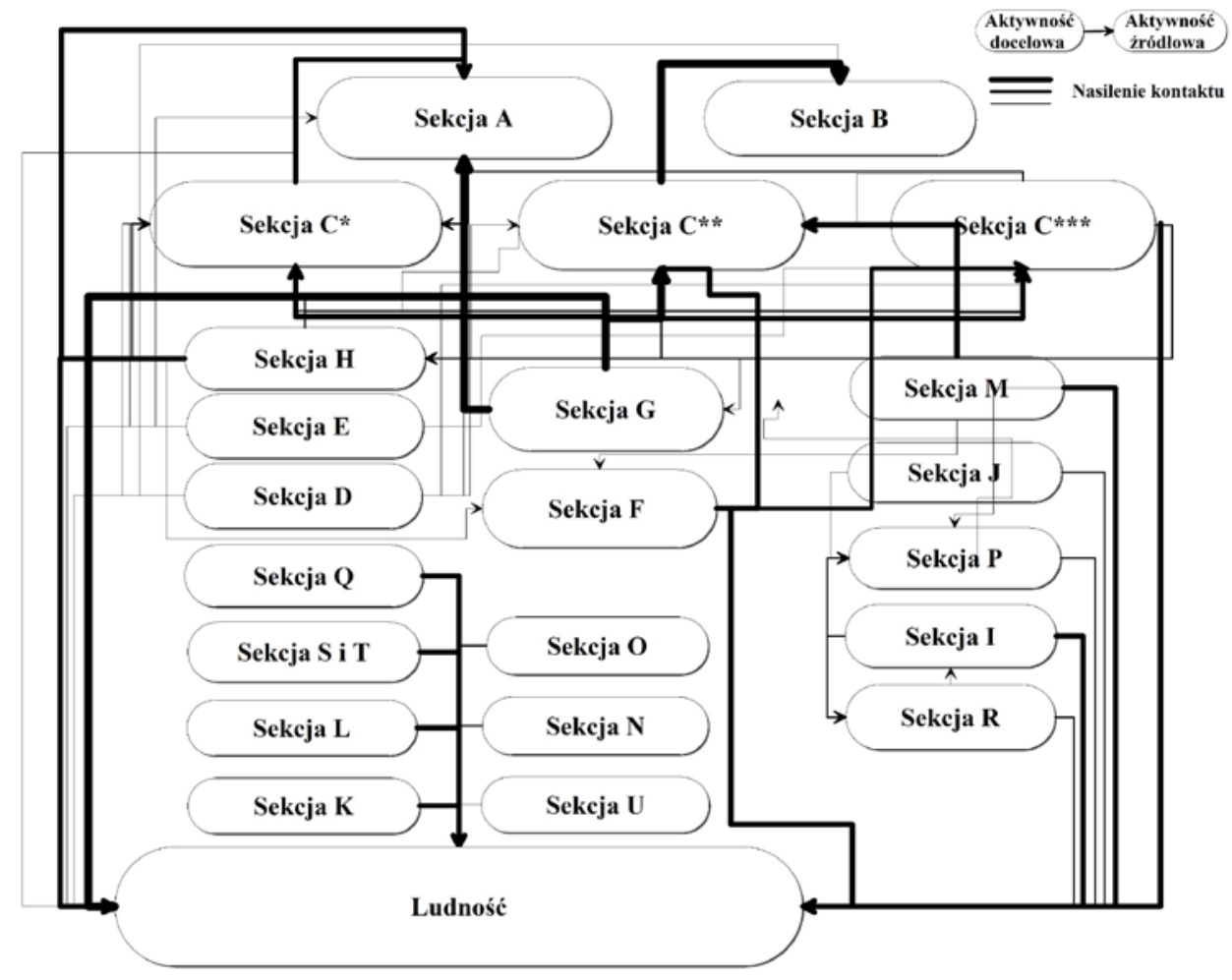

Źródło: opracowanie własne

Kontakty między przedsiębiorstwami rozumiane są jako zjawisko kooperacji, przepływ dóbr materialnych i niematerialnych, wzajemne relacje w tworzeniu podaży i popytu, wpływające na wzajemne rozmieszczenie i koncentrację aktywności. Badanie relacji między różnymi przedsiębiorstwami jest zagadnieniem bardzo szerokim, zależnym od badanego obszaru, jego struktury społeczno-gospodarczej. Konstrukcja sieci kontaktów została wykonana w sposób subiektywny, według własnych przesłanek i doświadczeń (ryc. 3).

Najsilniej powiązany został sektor produkcyjny, w którym występują liczne relacje poziome i pionowe związane z łańcuchem produkcyjnym, często ze wspólnymi: bazą surowcową, dystrybucją, popytem na kwalifikacje i nowe rozwiązania technologiczne. Relacje te wpływają na wzajemne rozmieszczenia aktywności dążących do optymalnej lokalizacji, podobnie jak aktywności związane z transportem, gdzie odpowiednia lokalizacja względem licznych źródeł (produkcja, sklepy i sieci handlowe) znacznie podwyższa efektywność. W tym przypadku koncentracje takich działalności mocno obniżają koszty dystrybucji, a także mogą przyczynić się do zwiększenia konkurencji firm na arenie globalnej poprzez inicjowanie współpracy. Kolejną silnie powiązaną grupą aktywności są przedsiębiorstwa usługowe, które zostały skontaktowane z aktywnością 
Ludność. Powiązane zostały także sekcje związane z edukacją, działalnością profesjonalną, techniczną i naukowo-badawczą, sektory produkcyjne i budownictwo.

Jednym z parametrów charakteryzujących poszczególne kontakty jest nasilenie kontaktu. Jest to miara stopnia powiązania ze sobą kontaktujących się aktywności. Jednocześnie wyraża ono wagę, jaką przykłada się do tego powiązania w modelowaniu, zwłaszcza gdy aktywność celowa jest powiązana z większą ilością źródeł. W zależności od celu wykorzystania modelu parametr ten mogą opisywać różnego typu dane, określające dążność jednostki źródła do przyciągnięcia ku sobie aktywności celowych $\mathrm{w}$ ramach danego typu kontaktu. Jako jednostkę aktywności przyjęto liczbę przedsiębiorstw, dlatego nasilenie powinno określać siłę relacji między przedsiębiorstwami. Określając listę kontaktów, z góry zakładamy istnienie przestrzennych relacji między parą aktywności, a dokładniej takiego oddziaływania aktywności źródłowych, które jest w stanie wpłynąć na rozmieszczenie aktywności celowych. Zakładając prawdziwość tego założenia, w rzeczywistości relacja taka powinna mieć odzwierciedlenie w zaistnieniu aktywności celowej na określonym obszarze spowodowanej aktywnością źródłową. Nasilenie kontaktu przedstawione jest zatem jako wskaźnik określający, ile przedsiębiorstw z sekcji celowej przypada na jedno przedsiębiorstwo źródłowe, średnio na całym obszarze badawczym, co w dużym uogólnieniu może być interpretowane jako siła i dążność sekcji źródłowej do przyciągania aktywności z sekcji celowej.

\section{PREDYSPOZYCJE TERENOWE}

Procedura predyspozycji jest traktowana przez model jako osobny czynnik wpływający na lokalizację aktywności. Czynnik ten można interpretować jako miarę atrakcyjności lokalizacyjnej rejonu, posiadającego stałe walory odpowiednie dla modelowanej aktywności. W modelowanym wariancie poddano tej procedurze te aktywności, które są silnie związane z zasobami naturalnymi: Sekcja A - rolnictwo, leśnictwo, łowiectwo i rybactwo (ryc. 4), oraz Sekcja B - górnictwo i wydobywanie (ryc. 5).

Ocena predyspozycji związana z sekcją A została oparta na opracowaniu T. Witka (1977). Dotyczy ono waloryzacji przestrzeni dla całej Polski, bez podziałów administracyjnych, gdzie podstawą ogólnej oceny była ocena warunków agroekologicznych, takich jak jakość gleb, rzeźba terenu, klimat i stosunki wodne. Wyniki przedstawione zostały w formie mapy, z 10-stopniową oceną. W przypadku parametryzacji modelu ocenie predyspozycji podlegają jednostki obliczeniowe, w tym przypadku gminy, dlatego konieczne było oszacowanie oceny w podziale administracyjnym gmin. Ocena predyspozycji dla każdej gminy została wykonana według metody:

$$
\text { ocena predyspozycji }=\sum_{x \in<1,10>}\left(\frac{A_{x}}{A} \cdot x\right),
$$

$x$ - ocena rolniczej przestrzeni produkcyjnej, $x \in<1,10>$,

$A_{x}$ - powierzchnia zajmowana przez obszar o danej ocenie (x) w gminie,

$A$ - całkowita powierzchnia gmin. 
Według wyżej przedstawionej metody gminy otrzymały ocenę predyspozycji mieszczącą się w przedziale od 1 do 10 (gdzie 10 - ocena maksymalna, 1 - minimalna). Modyfikacją ostatecznej oceny było obniżenie wartości predyspozycji dla miast do wartości 1, co związane jest z wypieraniem aktywności rolniczych z obszarów miejskich kosztem rozwoju innych funkcji, postępującą urbanizacją terenów podmiejskich, a także postulowanym rozwojem intensywnego rolnictwa. Wskaźnik ten wpłynie bezpośrednio na przesunięcia aktywności z tej sekcji i odnosi się do założenia, że efektywny rozwój rolnictwa powinien dążyć do kumulowania aktywności na terenach o najdogodniejszych warunkach agroekologicznych. Pomimo że wykorzystane opracowanie powstało dosyć dawno, dotyczy ono w dużej mierze warunków naturalnych, których dynamika zmian nie jest wysoka, a przy przyjętym stopniu uogólnienia modelu wydaje się być odpowiednią podstawą do ogólnego zróżnicowania poszczególnych gmin.

Ryc. 4. Ocena predyspozycji (warunków agroekologicznych) dla aktywności Sekcji A

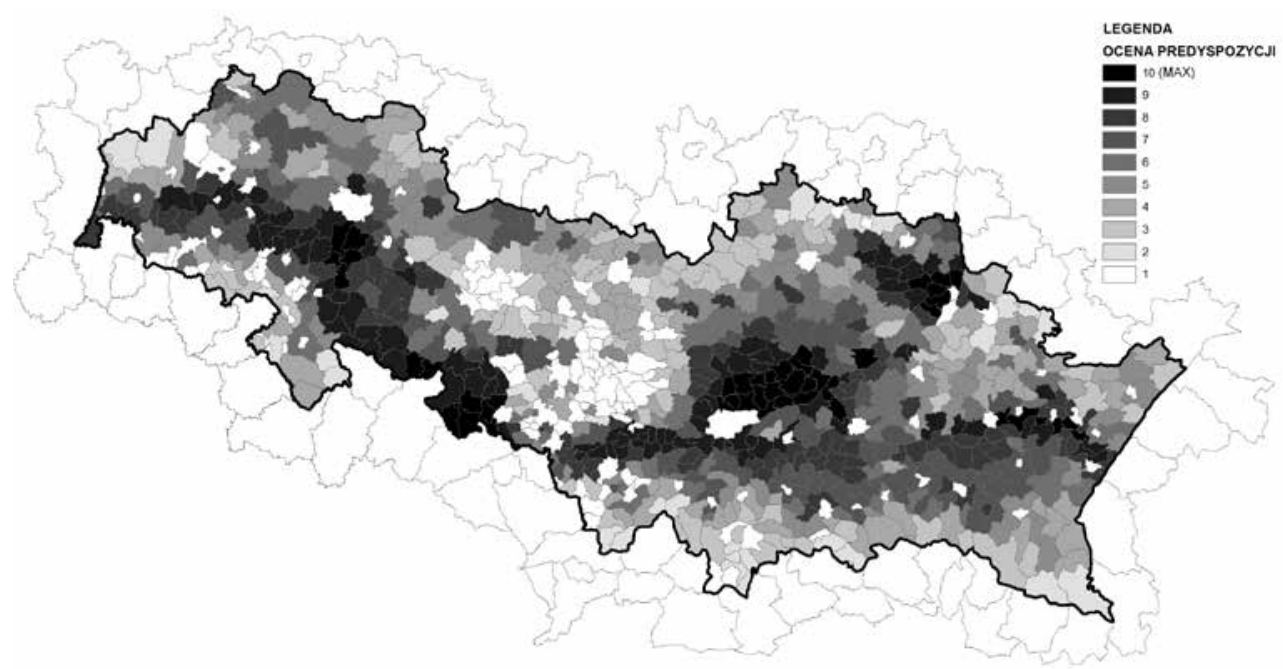

Źródło: opracowanie własne na podstawie: Witek (1977)

Ocenę predyspozycji dla sekcji B wykonano na podstawie danych publikowanych przez Państwowy Instytut Geologiczny - Państwowy Instytut Badawczy, a dokładniej danych na temat lokalizacji udokumentowanych złóż kopalnianych zamieszczonych w Centralnej Bazie Danych Geologicznych. Dane dotyczą wszystkich typów złóż, zarówno surowców energetycznych, budowlanych, chemicznych i pozostałych, jak i wód mineralnych. Należy zwrócić uwagę, że część złóż, uwzględniając obecny poziom rozwoju technologicznego i gospodarczego, jest nierentowna, ze względu na trudność wydobycia, ochronę środowiska naturalnego czy brak wizji powiązania przedsiębiorstwa wydobywczego z pozostałymi sekcjami gospodarczymi. Celem opracowania jest jednak próba koordynacji sekcji gospodarczych uwzględniająca tło prognostyczne, w którym zakłada się także rozwój technologii i sektora badawczego, dlatego niewątpliwie samo występowanie zasobów naturalnych wpływa na potencjał rozwojowy obszaru i ten właśnie czynnik określa ocenę predyspozycji dla sekcji B. 
Ocena predyspozycji została oszacowana na podstawie wskaźnika sumującego powierzchnie wszystkich złóż w danej gminie. Rzeczywisty potencjał złoża nie zależy jedynie od jego wielkości, ale także od cenności i jakości kruszywa; ze względu na brak takiej charakterystyki miara oceny wskazuje na prawdopodobieństwo wykorzystania tych kopalin.

Ryc. 5. Ocena predyspozycji (występowania złóż) dla aktywności Sekcji B

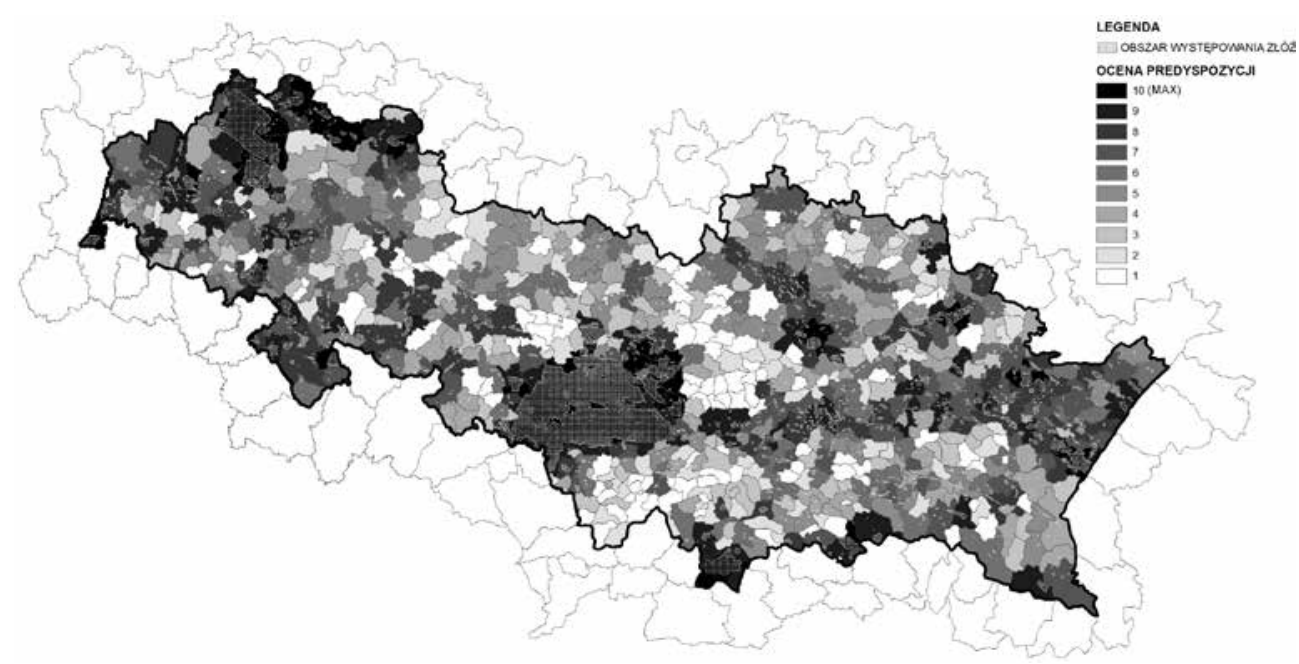

Źródło: opracowanie własne na podstawie danych z Państwowego Instytutu Geologicznego

\section{STAN WEJŚCIOWY}

Konstrukcja procedury kontaktów i predyspozycji koduje mechanizm modelu; przeprowadzenia symulacji konieczne jest ustalenie stanu wejściowego. Przed przedstawieniem tego etapu badań konieczne jest wprowadzenie dwóch pojęć z terminologii modelu Orion: aktywności zdeterminowane i niezdeterminowane. Aktywności te w jednakowym stopniu podlegają procedurom symulacyjnym, jednak przesunięciom podlegają jedynie aktywności niezdeterminowane. W przedstawionym wariancie symulacyjnym Ludność nie podlega przesunięciom; postulowany jest kontakt, w którym to lokalizacja przedsiębiorstw jest zależna od ludności, dlatego aktywność ta w całości ma charakter zdeterminowany, czyli trwale ustalony.

Jednym z głównych założeń pracy badawczej było zbadanie przesunięć i koncentracji jednostek gospodarczych przy zachowaniu prognostycznego charakteru badań; przeprowadzono badanie zmian liczby przedsiębiorstw $\mathrm{z}$ danych sekcji w okresie 1995-2012 (Bank Danych Lokalnych) i na podstawie ekstrapolacji trendu oszacowano globalną liczbę przedsiębiorstw dla całego obszaru, gdzie w badanym okresie następował stopniowy wzrost liczby przedsiębiorstw we wszystkich sekcjach, a więc zakłada się ciągłość tego procesu i prognostyczny, globalny wzrost do roku 2030. 
Nowa prognozowana liczba przedsiębiorstw jest właśnie sklasyfikowana jako aktywności niezdeterminowane; ich globalna liczba została rozmieszczona równomiernie na wszystkie rejony, co wyrównuje szansę między terenami i pozwoli zaobserwować kształtowanie się nowych, potencjalnych koncentracji; ich nowe, konkretne lokalizacje będą symulowane przez model. Postanowiono także uwzględnić potencjalne zmiany w stanie rzeczywistym (rok 2012), dlatego pewna część rzeczywistej liczby przedsiębiorstw w każdej gminie również została określona jako aktywność niezdeterminowana, mogąca ulec przemieszczeniu.

W odniesieniu do rzeczywistych procesów gospodarczych przesunięcia, jakim podlegną aktywności niezdeterminowane w procesie symulacyjnym, związane są z zaniknięciem przedsiębiorstwa z sekcji w danym obszarze i pojawieniem się w innym. Badania wskazały, że w większości przypadków sekcji stopniowe przyrastanie i rozpraszanie przedsiębiorstw wydaje się być procesem normalnym, związanym z rozwojem, zwiększającą się przedsiębiorczością ludności, stopniową specjalizacją i wykwalifikowaniem usług czy wyrównywaniem poziomu życia na obszarach słabiej zurbanizowanych. Problemem odmiennym jest zanik przedsiębiorstw, co może być związane bezpośrednio z upadkiem danego przedsiębiorstwa, ale także z tworzeniem się różnego rodzaju spółek, przekwalifikowywaniem działalności czy przenoszeniem siedziby firmy w inne miejsce. Problem zaniku przedsiębiorstw stał się podstawą do określenia stopnia niezdeterminowania danych aktywności.

Miarę stopnia niezdeterminowania określa procent udziału liczby upadłych przedsiębiorstw w badanym okresie (1995-2012) do liczby w okresie końcowym, czyli w roku 2012. Procent ten określa stopień „skłonności” przedsiębiorstw z danych sekcji do upadku.

Ryc. 6. Procentowy podział aktywności na zdeterminowane i niezdeterminowane (w stosunku do roku 2012) - stan wejściowy do symulacji

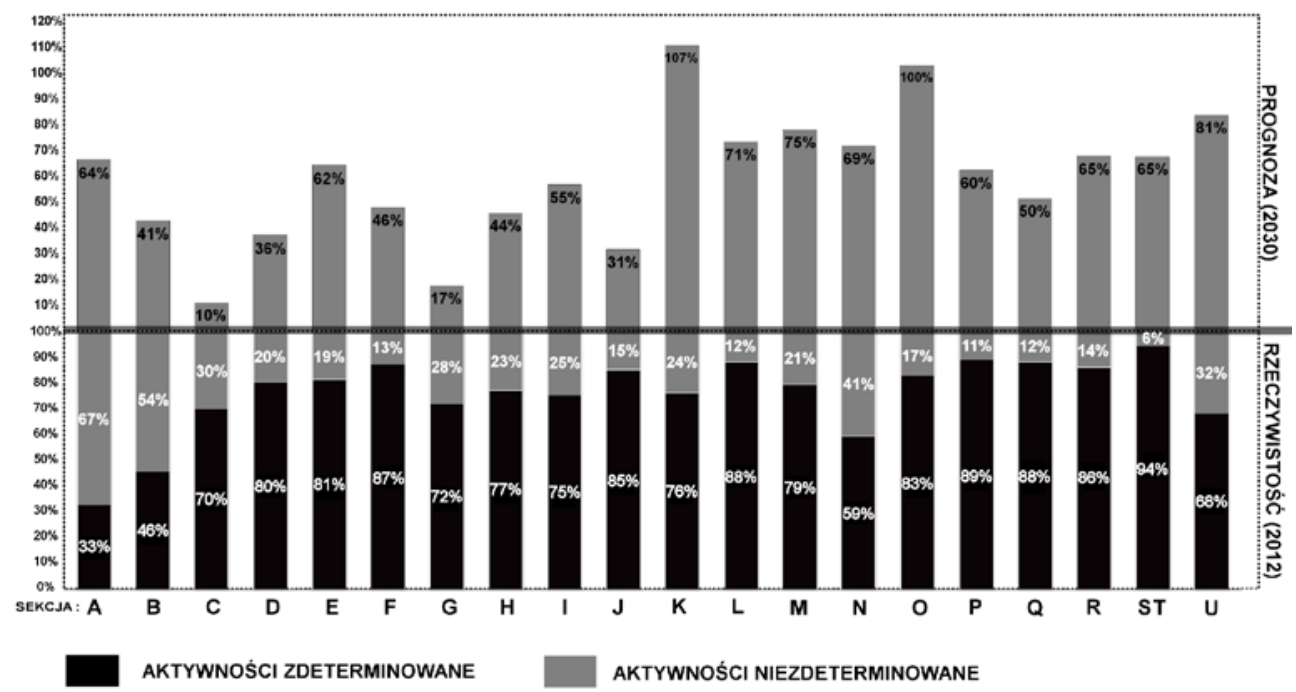

Źródło: opracowanie własne 
Najwyższy procent udziału aktywności niezdeterminowanej uzyskały sekcje A i B. W przypadku pierwszej sekcji jest to w dużej mierze spowodowane stopniowym odrolnianiem terenów na inne cele, przekwalifikowywaniem działalności rolniczej. W tej sekcji, a w sekcji B i innych, duży wpływ na taki wynik miała też transformacja gospodarcza, w której wyniku zlikwidowane zostały liczne państwowe zakłady i kopalnie. Najniższy wskaźnik niezdeterminowania otrzymały sekcje S i T (około 6\%); są to przedsiębiorstwa prowadzące działalność w gospodarstwach domowych oraz pozostałe niesklasyfikowane usługi i działalności. Stabilność takich przedsiębiorstw związana jest przede wszystkim z trwałym związkiem lokalizacji przedsiębiorstwa i miejsca zamieszkania, co znacznie łagodzi skutki ewentualnych kryzysów finansowych i gospodarczych.

Podsumowując etap przygotowania modelu, mamy do czynienia z modelem przestrzennym obszaru południowej Polski i najbliższego otoczenia w postaci punktów węzłowych reprezentujących poszczególne gminy oraz zmodernizowanej sieci komunikacyjnej przenoszącej kontakty. W każdym punkcie węzłowym zlokalizowana jest odpowiednia liczba poszczególnych aktywności zdeterminowanych, która jest odzwierciedleniem stanu rzeczywistego i która pozostaje nienaruszona (w pewnym procencie) w całym procesie symulacji, oraz pewien ładunek prognozowanych aktywności niezdeterminowanych, które ulegną przemieszczeniom poprzez realizację procedury kontaktów i predyspozycji. Model będzie dążył do takiej struktury, która zminimalizuje globalne koszty kontaktów (rozumiane jako koszty odległości) oraz koszty predyspozycji, związane z niedopasowaniem aktywności do lokalnych warunków.

\section{WYNIKI SYMULACJI}

Ryc. 7. Zestawienie wyników symulacji

a) stan początkowy

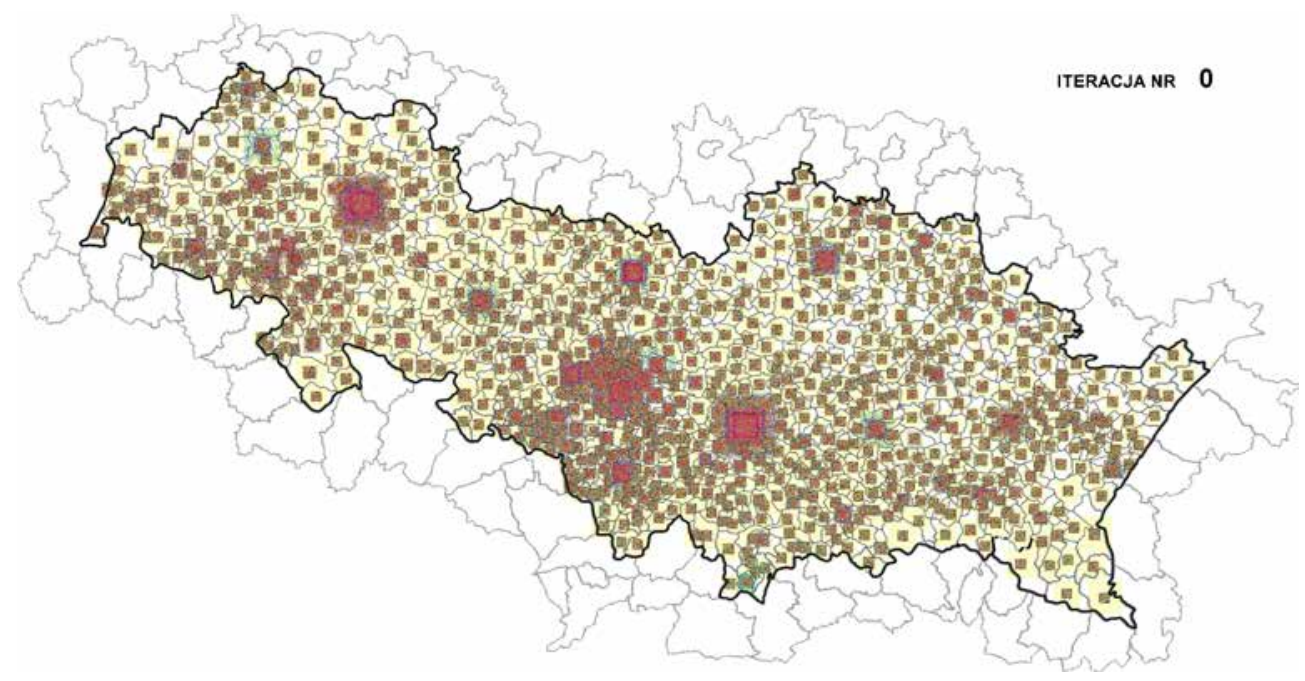


b) 2 iteracja

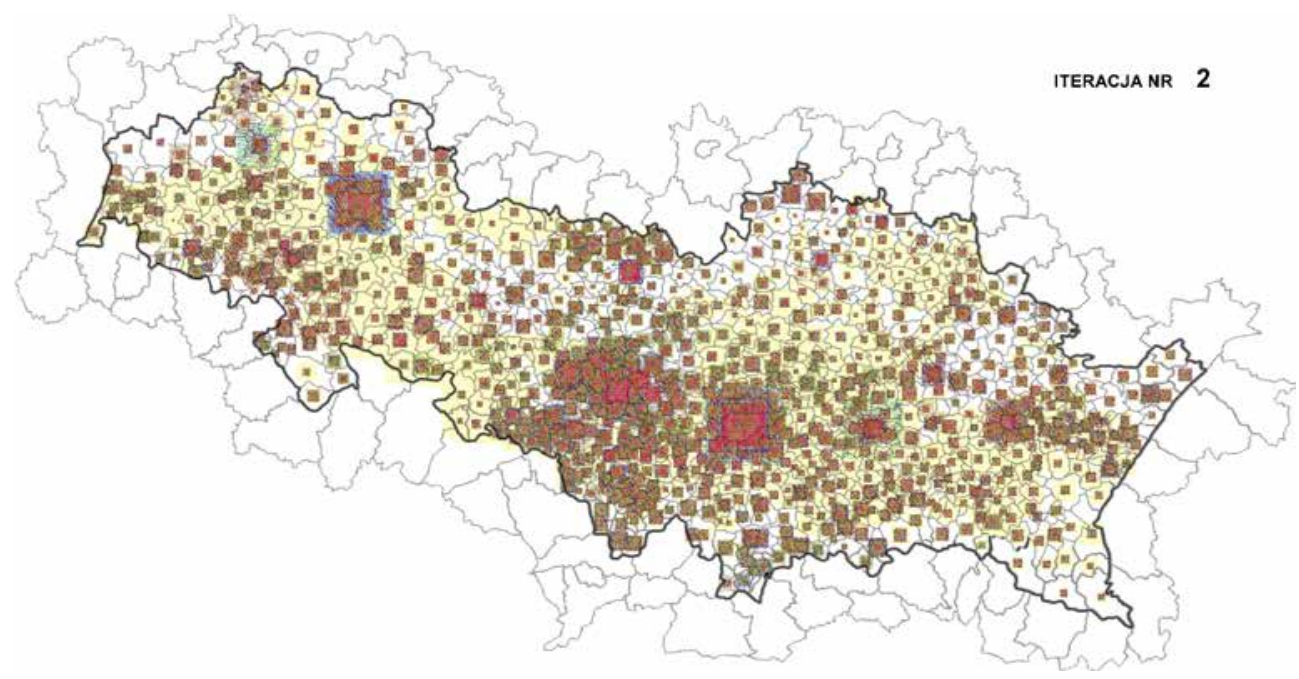

c) 10 iteracja

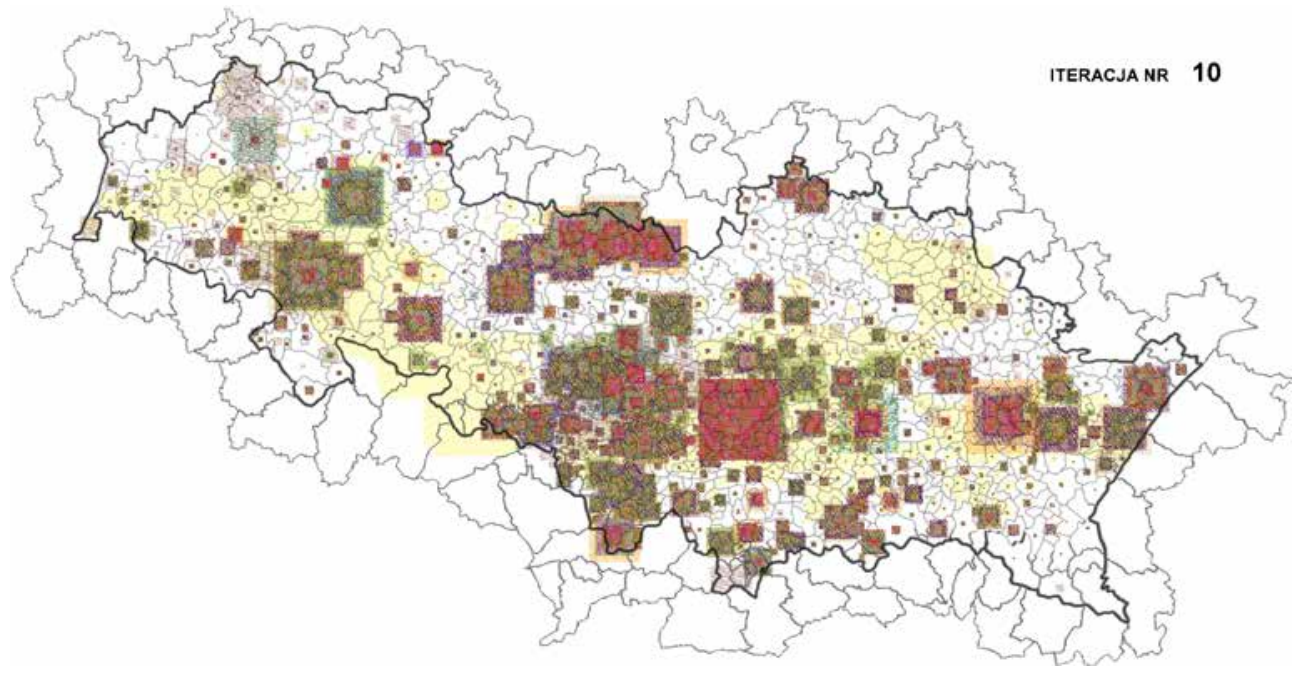

\begin{tabular}{|c|c|c|c|c|}
\hline SEKCJAA & SEKCJA D & SEKCJAI & SEKCJA N & SEKCJA S I T \\
\hline SEKCJA B & SEKCJAE & SEKCJA J & SEKCJA O & SEKCJA U \\
\hline SEKCJA C* & SEKCJAF F & SEKCJA K & SEKCJAP & \\
\hline SEKCJA C** & SEKCJA G & SEKCJAL L & SEKCJA Q & \\
\hline SEKCJA C... & SEKCJAH & SEKCJA M & SEKCJAR & \\
\hline
\end{tabular}

Źródło: opracowanie własne 
Przedstawione mapy pokazują wybrane etapy obliczeń symulacyjnych: stan początkowy (ryc. 7a), wynik 2 iteracji (ryc. 7b), gdzie możemy zaobserwować lokalne przesunięcia i koncentracje aktywności, oraz wynik iteracji 10 (ryc. 7c), gdzie w miarę narastających przybliżeń obliczeniowych następuje kształtowanie się megakoncentracji kosztem słabszych rejonów.

Te dwa zestawienia posiadają odmienny charakter: pierwsze zestawienie ma charakter prognostyczny; ogólna dynamika zmian w symulowanym okresie, czyli w latach 2012-2030, dla poszczególnych sekcji jest najbardziej zbliżona do dynamiki w analizowanym okresie 1995-2012. W zestawieniu drugim dochodzi do przeskalowania koncentracji, które raczej nie byłyby w stanie ukształtować się w rzeczywistości ze względu na liczne bariery - obraz ten wskazuje jednak szczególne miejsca ogniskowe, które według przyjętych założeń i braku znaczących ograniczeń w konstrukcji modelu charakteryzują się najwyższym potencjałem i efektywnością.

Należy zaznaczyć, że mapy przestawiają tylko aktywności niezdeterminowane podlegające przesunięciom, a każda z gmin posiada też pewien ładunek aktywności zdeterminowanych - całkowita utrata aktywności oznacza, że dana gmina nie była w stanie przyciągnąć prognozowanego globalnego wzrostu aktywności. Ze względu na duży obszar opracowania możemy zaobserwować wiele ciekawych przemian w skali lokalnej i regionalnej, m.in. znaczący spadek znaczenia Opola i Kielc na tle innych dużych miast, multifunkcjonalność Wrocławia i Krakowa, które przyciągnęły wszystkie typy działalności, wzrost Górnośląskiego Okręgu Przemysłowego, ukształtowanie się stref koncentracji miejscowości Świdnica-Dzierżoniów-Niemcza-Kondratowice-Marcinkowice, przesunięcie rozwoju z miasta Częstochowa na północne gminy i zawiązanie się pasmowej struktury koncentracji od miejscowości Kłomnice do miejscowości Ozimek poprzez Kruszynę, Rędziny, Opatów, Panki, Rudniki, Lipie czy Olesno, duży wzrost znaczenia miejscowości Łambinowice i Stąporków czy ukształtowanie się biegunów rozwojowych we wschodnich miejscowościach: Lubaczów, Radymno, Kańczuga, Leżajsk czy Grodzisko Dolne. Przywołane obserwacje dotyczą ogólnych procesów, ale część z nich pokrywa się z intuicyjnymi przewidywaniami, co może oznaczać, że skonstruowany model i przyjęte parametry przynajmniej w pewnym stopniu są zgodne z rzeczywistością. Poniżej przedstawiono ogólne uwagi dotyczące konstrukcji modelu, które określają ramy dla bardziej szczegółowych interpretacji wyników:

- model zakłada silną kooperację sektora produkcyjnego w wymianie produktów i półproduktów, wpływającą na wzajemną lokalizację przedsiębiorstw (sekcja C*, $\left.\mathrm{C}^{* *}, \mathrm{C}^{* * *}\right)$, nastawioną także na występowanie surowców zlokalizowanych i adaptowanych do obiegu przez sekcję A i B,

- w przypadku aktywności rolniczej i górniczej (sekcja A i B) nowe rozmieszczenie aktywności całkowicie zdeterminowane jest przez występowanie naturalnych walorów terenu, zakodowanych w procedurze predyspozycji; wiąże się to ze stopniową, efektywną eksploatacją zasobów kopalnianych oraz z kumulowaniem się produkcji rolniczej na terenach o najlepszych warunkach agrarnych, przy jednoczesnym wypieraniu tej aktywności z terenów mniej przydatnych,

- koncentracje aktywności związanych z transportem i magazynowaniem (sekcja H) uwzględniają silną kooperację z sektorem produkcyjnym, przemysłem 
rolno-spożywczym i materiałowym, ale także w dużej mierze skierowane są na potencjalny rynek zbytu, określony przez główne ośrodki osadnicze, ośrodki handlowe i obszary rozwoju budownictwa (w odniesieniu do transportu materiałowego),

- szeroka grupa sekcji usługowych została powiązana jedynie z aktywnością reprezentowaną przez ludność (sekcje K, L, N, O, Q, S i T, U); przez to uogólnienie obraz koncentracji tych aktywności jest silnie uproszczony; odmienne parametry modelowe kontaktów wpływają natomiast na różnice w dostosowywaniu się i wielkości koncentracji, które w ogólnej interpretacji świadczą o potencjale lokalizacyjnym ośrodków osadniczych,

- rozmieszczenie aktywności handlowych (sekcja G), podobnie jak sekcja H, również nastawione jest na szeroko pojęty sektor produkcyjny, jednak w największej mierze dostosowuje się do bezpośredniego odbiorcy usług - mieszkańców,

- w skonstruowanym modelu występuje współzależność między lokalizacją usług związanych z kulturą, rozrywką i rekreacją (sekcja R) oraz działalnością związaną z zakwaterowaniem i gastronomią (sekcja I),

- rozmieszczenie sekcji F - budownictwo, w największym stopniu związane jest z potencjałem ludnościowym, ale w pewnym stopniu na koncentrację wpływa także dobrze rozwinięty rynek materiałowy (sekcja $\mathrm{C}^{* *}$ ),

- aktywności związane z infrastrukturą - sekcja D (wytwarzanie i zaopatrywanie w energię elektryczną, gaz, parę wodną, gorącą wodę i powietrze do układów klimatyzacyjnych), sekcja E (dostawa wody, gospodarowanie ściekami i odpadami oraz działalność związana z rekultywacją) - lokują się w optymalnych miejscach obsługi ośrodków osadniczych, a także ośrodków przemysłowych, a w przypadku sekcji D, także w kontakcie z sekcją B jako dystrybutorem paliwa,

- najbardziej rozbudowana sieć kontaktów, zaadaptowana w strukturze modelu, dotyczy powiązania sektora przemysłowego, naukowo-badawczego i najbliższego otoczenia współpracy: koncentracje kooperujących aktywności przemysłowych powiązanych z sektorem transportowo-magazynowym i handlowym oraz z otoczeniem naukowo-badawczym, które koncentrują się wokół najważniejszych ośrodków edukacyjnych i nastawione są na kooperację z przedsiębiorstwami przemysłowymi, przetwórczymi, działalnością budowlaną i informacyjną; powiązanie takie stwarza potencjał do budowy efektywnych podsystemów wymiany informacji, innowacji, technologii, zarządzania, podnoszenia kwalifikacji pracowników, stworzenia odpowiedniego otoczenia prawnego, motywacyjnego oraz instytucjonalnego, podnosząc tym samym efektywność, innowacyjność i konkurencyjność regionu.

\section{ZAKOŃCZENIE}

Problematyka badań gospodarczych jest niezwykle szerokim i trudnym zagadnieniem, szczególnie w przypadku próby syntezy wielu czynników i relacji przestrzennych, gdzie nieodpowiednie dobranie parametrów czy nierzetelność danych modyfikują obraz całości i mogą silnie wpływać na wyniki; prawdopodobieństwo błędu rośnie wraz ze skomplikowaniem struktury modelowej. Praca badawcza przedstawia przykładowe 
podejście w całościowych analizach systemowych z zastosowaniem modelu Orion, który posiada duży potencjał w zaawansowanych analizach gospodarczych ze względu na wielowątkowość i możliwość kalibracji wielu parametrów.

Wynikowy stan struktury gospodarczej regionu i jego potencjalne wykorzystanie powinny być adekwatne do głównych założeń stosowanych przy konstrukcji modelu. Nowe rozmieszczenie aktywności w dużym stopniu uwzględnia stan rzeczywisty (czynnik zdeterminowania i niezdeterminowania aktywności) - model dokonał pewnej strukturyzacji lokalizacji aktywności, opartej na minimalizowaniu kosztów odległościowych między kontaktującymi się przedsiębiorstwami. Zbudowany model może posłużyć do eksperymentowania nad różnymi zachowaniami modelu w wyniku wprowadzanych modyfikacji i zmian parametrów, np. do obserwacji zmian otoczenia wywołanej przez powstanie danego typu działalności na konkretnym obszarze czy wpływu poprawy dostępności rejonów, precyzyjnego badania rozmieszczenia aktywności jednego typu w powiązaniu z potencjalnymi kooperantami, zwiększenia lub obniżenia wagi kosztów odległościowych w kontaktach między przedsiębiorstwami.

Badania nastawione na stymulowanie rozwoju gospodarczego niewątpliwie są jednymi z najważniejszych zagadnień, zrzeszających grono naukowców i badaczy mających na względzie dobro ogółu. Trajektoria rozwoju opartego na współpracy i szerzeniu wiedzy wydaje się być drogą najwłaściwszą, mogącą wpłynąć nie tylko na poprawę sytuacji gospodarczej, ale także mającą korzystny wpływ na społeczeństwo.

\section{Literatura}

\section{References}

Bank Danych Lokalnych (2013, 25 kwietnia). Pozyskano z http://www.stat.gov.pl/bdl/app/strona.html? _ name=indeks

Brzuchowska J., Litwińska, E., Ossowicz, T., Sławski, J., Zipser, T. (1994). Model symulacyjno-decyzyjny Orion. Wrocław: Oficyna Wydawnicza Politechniki Wrocławskiej.

Czech Statistical Office (2013, 25 kwietnia). Pozyskano z http://www.czso.cz/eng/redakce.nsf/i/home

Domański, R. (2006). Gospodarka przestrzenna. Warszawa: Wydawnictwo Naukowe PWN.

Koncepcja przestrzennego zagospodarowania kraju 2030 (2011). Warszawa: Ministerstwo Rozwoju Regionalnego.

Mamolo, M., Scherbov, S. (2009). Population Projections for Forty-Four European Countries: The Ongoing Population Ageing. Vienna: Vienna Inst. of Demography.

Państwowy Instytut Geologiczny - Państwowy Instytut Badawczy, Centralna Baza Danych Geologicznych (2013, 25 kwietnia). Pozyskano z http://www.pgi.gov.pl/

Perreur, J. (1992). Lokalizacja jednostek produkcyjnych. W: Ekonomiczna analiza przestrzenna. Praca pod kier. C. Ponsarda. Poznań: Wydawnictwo Akademii Ekonomicznej w Poznaniu.

Ponsard, C. (1992). Ekonomiczna analiza przestrzenna. Poznań: Wydawnictwo Akademii Ekonomicznej w Poznaniu.

Prognoza dla powiatów i miast na prawie powiatu oraz podregionów na lata 2011-2035 (2011). Warszawa: Główny Urząd Statystyczny.

Program budowy dróg krajowych na lata 2011-2015 (2013). Warszawa: Generalna Dyrekcja Dróg Krajowych i Autostrad.

Regional population projections, EUROPOP 2008: Most EU regions face older population profile in 2030 (2010) (2013, 25 kwietnia). Pozyskano z http://ec.europa.eu/

Regulski, J. (1985). Przestrzenne procesy rozwoju. W: Planowanie przestrzenne. J. Regulski (red.). Warszawa: Państwowe Wydawnictwo Ekonomiczne.

State Statistics Service of Ukraine (2013, 25 kwietnia). Pozyskano z http://ukrstat.org/en 
Statistical Office of the Slovak Republic (2013, 25 kwietnia). Pozyskano z http://portal.statistics.sk/showdoc. do?docid $=3159$

Törnqvist, G. (1977). The Geography of Economic Activities: Some Critical Viewpoint on Theory and Application. Economic Geography, 53, 153-162.

Witek, T. (1977). Waloryzacja rolniczej przestrzeni produkcyjnej Polski. Warszawa: Wydawnictwa Geologiczne. Zipser, T., Sławski, J. (1988). Modele procesów urbanizacji. Warszawa: Państwowe Wydawnictwo Ekonomiczne.

Michał Krygier, magister inżynier, Politechnika Wrocławska, Wydział Architektury, Katedra Planowania Przestrzennego. Ukończył studia I i II stopnia na Politechnice Wrocławskiej na kierunku Gospodarka Przestrzenna. Jego praca naukowa koncentruje się przede wszystkim na systemowym podejściu do szeroko pojętego planowania przestrzennego oraz na poznawaniu i praktycznym wykorzystywaniu modeli informatycznych i narzędzi symulacyjnych.

Michał Krygier, M.Sc., graduated first and second degree of the Wrocław University of Technology in Spatial Planning specialization. His scientific work focuses primarily on systemic approach to the wider spatial planning and getting to know and practical use of information models and simulation tools.

\section{Adres/address:}

Politechnika Wrocławska

Wydział Architektury

Katedra Planowania Przestrzennego

ul. Bolesława Prusa 53/55, 50-317 Wrocław, Polska

e-mail: michal.krygier@pwr.edu.pl 